\title{
PERAN GURU BIMBINGAN DAN KONSELING ANAK USIA DINI DALAM PENGEMBANGAN POTENSI ANAK INKLUSI DI TK NURUL HUDA KABUPATEN KARANGASEM BALI
}

\author{
Ulunia Safitri', Ilzam Dhaifi' \\ ${ }^{1}$ Pendidikan Islam Anak Usia Dini, Tarbiyah, Universitas Ibrahimy Situbondo \\ ${ }_{2}^{2}$ Pendidikan Islam Anak Usia Dini, Tarbiyah, Universitas Ibrahimy Situbondo \\ E-mail: uluniasafitri@gmail.com
}

\begin{abstract}
ABSTRAK: Pengembangan potensi pada anak inklusi dilakukan dengan cara metode pembelajaran kelompok dan guru kelas serta guru pembimbing yang menggunakan strategi masing-masing sesuai dengan kebutuhan peserta didik. Permasalahan yang dikaji dalam penelitian ini adalah (1) Bentuk pembelajaran di kelas dalam pengembangan potensi anak inklusi (2) Faktor penghambat dalam pengembangan potensi anak inklusi (3) Hasil dari guru dalam pengembangan potensi anak inklusi. Jenis penelitian ini merupakan jenis penelitian kualitatif deskriptif yang mengambil lokasi di TK Nurul Huda Kabupaten Karangasem Bali. Pengumpulan data dilakukan dengan melakukan observasi, wawancara, dan dokumentasi. Analisis data dilakukan dengan memberikan makna terhadap data yang berhasil dikumpulkan, kemudian dari makna itulah ditarik kesimpulan. Pemeriksaan keabsahan data dilakukan dengan triangulasi. Hasil penelitian menunjukkan (1) Bentuk pembelajaran yang dilakukan di TK Nurul Huda adalah bentuk pembelajaran kelompok, dengan menyatukan peserta didik reguler dengan peserta didik inklusi (ABK) di bawah pengawasan guru kelas dan guru pendamping khusus. (2) Faktor penghambat dalam pengembangan potensi anak inklusi adalah sarana dan prasarana yang kurang memadai, kurangnya guru pendamping khusus. (3) Hasil dari pengembangan potensi anak inklusi cukup baik dan membanggakan bagi kepala sekolah, guru, maupun orang tua peserta didik.
\end{abstract}

Kata Kunci: Bimbingan Konseling; Potensi Anak Inklusi

\begin{abstract}
Potential development in inclusive children is done by means of group learning methods and classroom teachers and supervisors who use their respective strategies according to the needs of students. The problems examined in this study are (1) The form of learning in the classroom in the development of the potential of inclusive children (2) Inhibiting factors in developing the potential of an inclusive child (3) The results of the teacher in developing the potential of an inclusive child. This type of research is a type of descriptive qualitative research that took place in TK Nurul Huda, Karangasem Bali Regency. Data collection is done by conducting observations, interviews, and documentation. Data analysis is carried out by giving meaning to the data that was collected, then from that meaning conclusions are drawn. Checking the validity of the data is done by triangulation. The results showed (1) The form of learning conducted at TK Nurul Huda was a form of group learning, by uniting regular students with inclusive students (ABK) under the supervision of class teachers and special assistant teachers. (2) Inhibiting factors in developing the potential of inclusive children is inadequate facilities and infrastructure, lack of special assistant teachers. (3) The results of the development of the potential of inclusive children are quite good and proud of the principal, teachers, and student's parents.
\end{abstract}

Keywords: Counseling guidance; Children of Inclusion Potential 


\section{PENDAHULUAN}

Bimbingan dan konseling adalah kebutuhan mandiri yang tak kalah penting dengan kebutuhan mata pelajaran yang didapat dalam kegiatan pembelajaran (Purnomo, 2001: 1). Artinya, dalam membentuk karakter siswa yang berkompeten tidak hanya diperlukan pada kegiatan dan proses pembelajaran tetapi juga perlu adanya layanan bimbingan dan konseling.

Pendidikan merupakan bimbingan atau pertolongan yang diberikan oleh orang dewasa kepada perkembangan anak untuk mencapai kedewasaan yang bertujuan agar anak dapat melaksanakan tugas hidupnya sendiri tanpa bantuan orang lain. Pendidikan ini adalah awal yang sangat penting untuk seorang anak, karena melatih mereka untuk membaca dengan baik, mengasah kemampuan berhitung serta berfikir. Saat ini, pendidikan di sekolah dapat ditempuh oleh siapapun dari berbagai kalangan dan golongan. Berbagai sekolah didirikan untuk menjadi tempat atau sarana pendidikan bagi anak, tanpa terkecuali anak-anak berkebutuhan khusus. Berbagai kurikulum juga dikembangkan untuk sekolah agar dapat membantu anak dalam proses pembelajaran yang baik dan bermutu (Takdir ilahi, 2013: 15).

Pendidikan memegang peranan sangat penting dalam meningkatkn sumber daya manusia yang unggul dan kompetitif dalam upaya menghadapi tantangan perubahan dan perkembangan zaman yang semakin meningkat tajam.untuk mencapai tujuan idealism pendidikan, tentu diperlukan komitmen dalam membangun kemandirian dan pemberdayaan yang mampu menopang kemajuan pendidikan dimasa mendatang.

Menurut UU RI Nomor 20 tahun 2003 tentang SIKDISNAS pasal 1 ayat 1 , Pendidikan pada hakikatnya adalah usaha sadar dan terencana untuk mewujudkan suasana belajar dan proses pembelajaran agar peserta didik secara aktiv mengembangkan potensi dirinya untuk memiliki kekuatan pengendalian diri, spiritual keagamaan, kepribadian, kecerdasan, akhlaq mulia, serta keterampilan yang diperlukan dirinya, masyarakat, bangsa, dan Negara.

Siswa merupakan individu yang memiliki perbedaan antara satu dan yang lainnya. Dalam perkembangannya, setiap diri siswa dapat dipastikan memiliki masalah-masalah individu yang berbeda pula baik masalah pribadi, sosial, maupun akademiknya. Masalah-masalah siswa disekolah dapat dikatagorikan menjadi lima yaitu: Perkembangan individu; perbedaan individu (kecerdasan, hasil belajar, bakat, sikap, kebiasaan, pengetahuan, kepribadan fisik, latar belakang lingkungan, dan lainlain); Kebutuhan individu (harga diri, kasih sayang penghargaan, ingin dikenal, prestasi dan posisi, rasa aman dan perlindungan diri); penyesuaian diri dan tingkah laku; masalah belajar.

Guru bimbingan dan konseling berperan dalam hal ini membantu siswa dalam memecahkan permasalahan yang sedang dihadapinya, tetapi juga membantu mengembangkan kualitas pribadi siswa agar mampu berkembang secara optimal karena anak usia dini merupakan individu yang sedang dalam proses perkembangan menuju kedewasaan. Maka guru bimbingan dan konseling hendaknya mampu memberikan layanan bimbingan yang mengarah kepada keberhasilan perkembangan siswa dari seluruh aspek perkembangan yang dimiliki oleh anak.

Pendidikan bagi anak berkebutuhan khusus saat ini terus mengalami evolusi seiring dengan perkembangan teknologi yang ikut serta mempengaruhi perubahan dalam sistem pembelajaran. Cara pandang terhadap layananan pendidikan juga mengalami perubahan yang semakin mempermudah anak didik berkreasi dan terampil dalam mengembangkn potensi pribadinya yang terpendam. 
TK Nurul Huda merupakan salah satu dari beberapa TK yang ada di Karangasem yang mampu membina anak inklusi agar bisa berkembang dengan baik. TK Nurul Huda juga bisa dikatakan sebagai salah satu TK yang mana didalamnya mampu membina anak dengan berbagai macam karakteristik siswa baik yang normal maupun anak inklusi (Autisme, Hiperaktif, Pendiam, lambat belajar, dll) itu sendiri.

Proses pembelajarannya, sama seperti sekolah-sekolah TK lainnya yakni dijadikan satu atau dicampur dengan siswa normal lainnya. Hal ini dikarenakan agar anak-anak inklusi lainnya bisa atau mampu berkomunikasi dengan teman-temannya. Karakteristik siswa berkebutuhan khusus di TK Nurul Huda sendiri diantaranya adalah siswa yang autisme, lambat belajar, dan anak yang hiperaktif. Banyak siswa berkebutuhan khusus lainnya yang memiliki keadaan kurang dinamis, seperti mengganggu teman lain, kurang percaya diri, menangis ketika ada sedikit gangguan, meniru tindakan orang lain, dan juga sulit dalam memahami pelajaran.

Siswa berkebutuhan khusus di TK Nurul Huda memiliki pribadi-pribadi yang unik karena karakteristiknya yang berbedabeda dalam proses perkembangannya. Siswa ini tidak hanya memerlukan pendampingan dari orang tua tetapi juga dari guru kelasnya atau guru bimbingan konseling itu sendiri. Terkait dengan masalah-masalah yang di timbulkan, maka peran guru bimbingan dan konseling diharapkan dapat memecahkan berbagai macam persoalan yang di timbulkan oleh anak-anak inklusi agar mengarah kepada perkembangan yang lebih dinamis. Berdasarkan uraian di atas, diperoleh gambaran jelas yang dapat menarik perhatian peneliti untuk melakukan penelitian di TK Nurul Huda Karangasem Bali yaitu untuk mengetahui peran guru bimbingan dan konseling anak usia dini dalam pengembangan potensi anak inklusi kelompok B.

\section{METODE PENELITIAN}

Peneliti dalam penelitian ini menggunakan jenis penelitian dengan studi kasus. Studi kasus adalah suatu penelitian yang mendeskripsikan dan menganalisa secara intensif, terinci, dan mendetail terhadap suatu organisasi, lembaga atau gajala tertentu (Sugiyono, 2013: 9). Dalam artian, bahwa peneliti difokuskan pada suatu masalah yang ingin dipilih dan ingin dipahami secara mendalam dengan tujuan untuk memperoleh deskripsi yang utuh.

Lokasi penelitian di sekolah TK Nurul Huda Kabupaten Karangasem Bali. Dengan jumlah siswa keseluruan baik dari kelas A, B dan KB yaitu 97 siswa. Kelas A berjumlah 25 anak, kelas B berjumlah 62 anak dan KB berjumlah 10 anak. Fokus subjek penelitian yaitu pada siswa kelas B. Tehnik pengumpulan data dapat dilakukan pada natural setting (kondisi yang alamiah) proses yang dilakukan untuk pengumpulan data berupa observasi, wawancara, dan dokumentasi.

\section{PEMBAHASAN}

Bentuk Pelaksanaan Pembelajaran dalam Pengembanagan Potensi Anak Inklusi

Model pembelajaran bagi anak inklusi di TK Nurul Huda adalah model pembelajran kelompok, yaitu bentuk bimbingan yang diberikan kepada beberapa siswa secara bersamaan yang sebelumnya telah dibentuk menjadi dua kelompok dari seluruh jumlah siswa yang ada di dalam kelas, dalam kegiatan pembelajaran tersebut guru tidak memisahkan antara anak inklusi dengan anak reguler tetapi digabungkan menjadi satu dalam satu kelompok, dengan tujuan agar anak inklusi maupun anak reguler lebih cepat beradaptasi dan lebih memudahkan guru bimbingan dalam mengamati proses perkembangan potensi anak-anak terutama anak inklusi.

Penerapan model pembelajaran kelompok yang telah dilaksanakan di TK Nurul Huda ini diasumsikan dapat mengembangkan potensi anak inklusi, 
karena dengan mnggunakan model pembelajaran kelompok guru lebih mudah dalam mengamati perkembangan potensi anak inklusi. Namun, keberhasilan perkembangan potensi anak inklusi juga tergantung dari cara orang tua dalam mendidik anak-anaknya ketika berada di rumah, sebab kondisi lingkungan juga berpengaruh dalam mewujudkan potensi anak.

Latar belakang pengembanagan potensi anak inklusi yang dipengaruhi oleh dua factor menurut munich sudah dianggap benar, karena kondisi lingkungan, yakni lingkungan keluarga, sekolah dan teman sebaya merupakan perangsang bagi pengembangan potensi anak inklusi. Potensi anak-anak di TK Nurul Huda banyak sekali, utamanya dalam bidang keagamaan dan seni, untuk anak inklusi sendiri potensinya lebih banyak ada dalam bidang seni, seperti mewarnai, melukis, seni drum band, menggambar dan seni angklung, dan tidak jarang juga anak inklusi di TK Nurul Huda ini sering ikut dalam perlombaan-perlombaan yang diadakan oleh kabupaten maupun provinsi.

Pengembangan potensi anak inklusi di TK Nurul Huda dalam pengembangannya, pihak sekolah menggunakan waktu di luar jam sekolah yang dilaksanakan setiap hari rabu dan sabtu ( 1 minggu 2x), hal itu dilakukan pihak sekolah dengan tujuan agar lebih cepat dalam proses mengembangkan potensipotensi anak inklusi dan anak-anak berbakat lainnya. Model pembelajaran kelompok di TK Nurul Huda sudah berjalan efektif, ditinjau dari berbagai sarana dan prasarana yang telah disediakan pihak sekolah, dan proses pembelajarannya sudah berjalan lancer, karena adanya bantuan dari guru pendamping khusus dalam kelas yang bisa menangani berbagai macam permasalahan dalam kelas yang ditimbulkan oleh anak inklusi terutama anak hiperaktif.

Efektifitas model pembelajaran kelompok di TK Nurul Huda bisa dikatakan cukup berhasil, karena dari model pembelajaran kelompok banyak ditemukan potensi-potensi anak inklusi yang terpendam dan perlu dikembangkan. Hal tersebut diwujudkan oleh giuru dan kepala sekolah dengan mendedikasikan anak-anak inklusi ke dalam berbagai ajang perlombaan.

Hal ini sebagaimana hasil peneliti, ketika guru sedang mengajar di depan kelas dan menjelaskan tentang materi yang akan diberikan kepada anak untuk nantinya dijadikan sebagai unjuk kerja dan penugasan, jumlah keseluruhan dalam kelas tersebut ada 26 siswa dan dibentuk manjadi 2 kelompok terpisah anatara laki-laki dan perempuan, namun pada hari itu ada 2 orang siswa yang tidak hadir karena sakit. Ketika guru menjelaskan tentang penugasan anak-anaknya dengan tenang mendengarkan guru, setelah selesai mendengarkan baru kemudian anak-anak mengerjakan tugas yang disuruh gurunya untuk mewarnai gambar yang ada di lembar kerja siswa masing-masing. Namun, ada salah satu anak yang bernama Azam merebut crayon milik Nabila teman sebelahnya padahal Nabila tidak mengizinkan Azam untuk mengambil crayonnya.

Azam terus mengusili Nabila karena Nabila yang pendiam, akhirnya Nabila menangis dan melapor kepada guru kalo si Azam nakal dan mengambil crayon Nabila tanpa izin. Akhirnya Azam diberikan nasehat sama guru pendamping kalo mengambil barang temannya tanpa izin itu tidak boleh. Tetap saja Azam berprilaku seperti itu karena Azam mengatakan sama guru kalo dia hanya ingin meminjam crayonnya saja tidak ingin merusak,tapi kalo kata Nsbila tidak boleh Azam tidak boleh memaksa "Kata Bu Guru". Karena Azam orangnya tidak begitu merespon apa kata guru pendampig kelas maka akhirnya azam keluar dari kelas dan bermain.

Guru terus membujuk Azam untuk belajar,dan dirayu kalo Nabila mau meminjami crayonnya asal tidak dirusak dan tidak di potong jadi dua. Akhirnya , Azam masuk kembali ke dalam kelas 
dengan didampingi guru pendamping sedangkan guru kelasnya melihat-lihat anak-anak yang lain yang sedang mengerjakan tugas.

Ada banyak alasan yang membuat pembelajaran kelompok digunakan dalam perkembangan potensi anak inklusi. Salah satunya adalah berupaya memberikan kesempatan kepada mereka yang mempunyai atau mengalami keterbatasan agar juga bisa mengenyam pendidikan secara layak dan memberikan jaminan masa depan yang lebih cerah, karena jika tidak demikian, dikhawatirkan akan menjadi boomerang tersendiri bagi anak inklusi sehingga menjadikan mereka tidak percaya diri dalam melakukan aktifitas yang berkaitan dengan masa depannya.

Alasan yang dikemukakan oleh Mohammad Takdir Ilahi dalam bukunya sudah dianggap sesuai, sebab pendidikan di Negara ini tidak hanya diperuntukkan untuk orang-orang normal tetapi juga untuk anak-anak inklusi yang memiliki kekurangan maupun kelebihan, untuk mengantisispasi terjadinya kekhawatiran maka di Indonesia telah dibentuk sekolah inklusif yang memastikan anak inklusi berkumpul bersama dengan anak reguler dalam satu sekolah penuh dan dalam satu kelas penuh tanpa ada perbedaaan di dalamnya yang dibuat kelompok kecil untuk mengidentifikasi perkembangan potensi.

Evaluasi dalam model pembelajaran ini dengan bentuk pengamatan, unjuk kerja dan penugasan. Pengamatan itu sendiri merupakan salah satu cara untuk mengetahui potensi-potensi yang dimiliki oleh anak-anak inklusi, sedangkan untuk penugasan dan unjuk kerja dilakukan ketika anak-anak mengerjakan tugas yang ada dibuku LKS, untuk memantau perkembangan potensi anak inklusi maka kepala sekolah juga melakukan kerja sama dengan orang tua siswa dalam berbagai macam bidang.

Harapan kepala sekolah dengan adanya pelaksanaan pembelajaran kelompok adalah guru pendamping khusus yang ada di kelas lebih mudah mengamati perkembangan potensi anak inklusi sebab dalam satu kelompok belajar hanya ada beberapa anak inklusi beda halnya dengan jika anak inklusi dikelompokkan atau digabungkan dalam satu kelas maka guru bimbingan khusus akan lebih sulit dalam mengamati proses perkembangan potensi anak inklusi. Selain itu hal lain yang ingin dicapai adalah terwujudnya pengembanagan potensi anak inklusi melalui pelayanan dari program bimbingan khusus dan diharapkan pula dari pihak guru maupun orang tua dapat terus memelihara potensi yang dimiliki anak inklusi.

\section{Faktor Penghambat dalam Mengembangkan Potensi Anak Inklusi}

Diantara factor penghambat dari peran guru Bimbingan dan Konseling Anak Usia Dini dalam pengembangan potensi anak inklusi adalah ketika anak-anak mulai jenuh dalam menerima dan mendengarkan materi pembelajaran yang disampaikan oleh guru, tidak hanya itu yang menjadi kendala dalam proses pembelajaran adalah guru pendamping khusus yang jarang masuk. Guru TK/PAUD dituntut agar bisa menyampaikan materi pembelajaran dengan berbagai macam strategi, agar anak tidak cepat jenuh.

Disamping hal di atas, yang menjadi factor penghambatnya adalah kurangnya guru pendamping khusus dan guru yang jarang masuk sekolah di TK Nurul Huda, sebab guru pembimbing khusus merupakan salah satu sarana terpenting dalam proses perkembangan potensi anak inklusi. Chris dukes dan Maggie smith (2009) di dalam bukunya mengatakan bahwa setiap anak memerlukan pengawasan serta pendamping, karena pendamping memegang peran sebagai layanan koordinasi.

Dari factor penghambat yang dialami oleh guru dan kepala sekolah, mereka berusaha memecahkan dan menangani berbagai macam persoalan yang ditimbulkan oleh anak inklusi, salah satunya ialah dengan guru melakukan berbagai pendekatan-pendekatan khusus, 
sedangkan kepala sekolah sendiri melakukan pertemuan dengan orang tua siswa sebagai antisispasi terjadinya kasus yang sering ditimbulkan oleh anak-anak inklusi. Kepala sekolah memberikan sosialisasi dan informasi terkait perkembangan anak-anaknya selama di sekolah, sehingga orangtua bisa mengevaluasi sendiri bagaimana perkembangan anak-anaknya ketika berada di rumah.

Dalam pengembangan potensi anak inklusi juga diperlukan sarana dan prasarana yang mendukung agar memudahkan bagi pihak sekolah dalam mengevaluasi berbagai macam potensi yang dimiliki oleh anak-anak inklusi, sebab jika tidak ada dukungan dari adanya sarana dan prasarana maka dalam mengembangkan potensi anak inklusi akan sulit.

\section{Hasil dari Peran Guru Bimbingan dan Konseling anak Usia Dini dalam Mengembangkan Potensi Anak Inklusi}

Evaluasi merupakan cara guru atau sekolah untuk mengetahui seberapa besar kemampuan anak dalam mengerjakan tugas-tugas sekolah. Cara evaluasi yang dilakukan di TK Nurul Huda sendiri berbeda beda, ada dengan cara pengamatan, unjuk kerja, dan penugasan. Pengamatan sendiri dilakukan oleh guru pembimbing khusus dalam mengembangkan potensi anak inklusi sedangkan untuk unjuk kerja sendiri dan penugasan dilakukan ketika anak-anak sedang mengerjakan LKS.

Menurut Erna Febru Aries, evaluasi dilakukan untuk menentukan keterampilan dan prestasi akademik dan non akademik yang dicapai siswa dan evaluasi ini dilakukan melalui analisis dan simpulan terhadap lembaran kerja siswa. Dari beberapa evaluasi dan bentuk evaluasi yang digunakan oleh guru dan kepala sekolah menggali hasil yang cukup baik meskipun ada beberapa kendala yang sering dihadapi oleh guru. Beberapa prestasi yang pernah diraih oleh anak inklusi adalah lomba mewarnai, menari, dan drumb band.
Di dalam buku karangan Uyu Wahyudi dan Mubiar Agustin menyatakan bahwa dengan adanya evaluasi maka dengan mudah seorang pendidik mendapat informasi tentang kinerja dan kemajuan berbagai aspek perkembangan yang dapat dicapai oleh peserta didik setelah mengikuti kegiatan-kegiatandalam kurun waktu tertentu.

Guru maupun pihak sekolah selalu memberikan informasi mengenai hasil dari perkembangan ank-anak mereka melalui bentuk kerja sama dan pertemuan bulanan yang sudah diagendakan sebelumnya oleh pihak sekolah. Hal tersebut dilakukan dengan tujuan agar para orang tua/ wali murid menjadi termotivasi untuk terus memperbaiki dan mengasah kemampuan potensi anak-anak mereka. Akan tetapi, mereka juga tetap mendapatkan kontrolan dan pengawasan dari pihak sekolah dan orang tua.

Dalam meningkatkan potensi anak, telah dilakukan berbagai macam cara oleh guru maupun pihak terkait, sehingga perlu adanya tindak lanjut yang harus dilakukan oleh guru untuk terus mengembangkan potensi anak. Tindak lanjut tersebut guru lakukan dengan cara memberikan informasi kepada kepala sekolah yang nantinya akan disosialisakan kepada orangtua atau wali murid. Menurut Chris Dukes dan Maggie, Pengontrolan terhadap anak berkebutuhan Khusus sangat penting sebab tidak jarang anak berkebutuhan khusus sering membuat permasalahan-permasalahan dan keributan kecil, sehingga sangat diperlukan pengawasan untuk meningkatkan kualitas perkembangan dari anak berkebutuhan khusus agar tetap berkembang dengan baik.

\section{KESIMPULAN}

Bentuk bimbingan yang dilakukan di sekolah ini adalah bentuk bimbingan kelompok, yakni bentuk bimbingan yang diberikan kepada beberapa siswa secara bersamaan karena dengan bentuk bimbingan kelompok itulah guru pembimbing dengan mudah bisa 
menganalisa berbagai macam bentuk potensi yang dimiliki oleh anak-anak inklusi di TK Nurul Huda khususnya dikelompok B. Proses pendampingan pembelajarannya sendiri yang dilakukan oleh guru pendamping khusus yang ada di kelas masing-masing kepada anak inklusi adalah menggunakan model pembelajaran individual.

Faktor penghambat proses pembelajaran inklusi, suasana belajar di dalam kelas kurang kondusif, guru pendamping yang sering tidak masuk sehingga anak inklusi ada yang menimbulkan permasalahan, guru kurang inovatif dalam menyampaikan materi pembelajaran, dan kurangnya guru pendamping khusus sehingga tidak jarang wali murid turut serta dalam pembelajaran.

Hasil yang didapat dari adanya peran guru bimbingan dan konseling adalah cukup membantu sekolah dalam menangani kasus-kasus yang sering ditimbulkan oleh anak-anak inklusi serta memudahkan sekolah juga dalam menganalisa potensi-potensi dari anka-anak inklusi.

\section{DAFTAR PUSTAKA}

Adita Pramanasari. 2015, " Peran Guru Bimbingan dan Konseling dalam Membina Kecerdasan Emosional dan Spritual Anak Berkebutuhan Khusus di SMP PGRI Kasihan Bantul Yogyakarta", Yogyakarta: UIN Sunan Kalijaga.

Daryanto dkk. 2015, "Bimbingan Konseling Paduan Guru BK dan Guru Umum", Yogyakarta: Penerbit Gava Media

Dukes Chris dan Maggie. 2009." Cara Menangani Anak Berkebutuhan Khusus", Jakarta: PT Tamaprint Indonesia

Dwi Wijayanti Aini. 2013, "Implementasi Bimbingan dan Konseling dalam meningkatkan kecerdasan emosi siswa Inklusi di MTS Negeri Sumbergiri, Panjang Gunung Kidul
Yogyakarta, "Yogyakarta: UIN Sunan Kalijaga.

Emzir. 2010. “Metode Penelitian Kualitatif Analisis Data”, Jakarta: PT. Raja Grafindo Persada

Erman dan Prayitno. 2008. “ Dasar-Dasar Bimbingan dan Konseling”, Jakarta: Rineka Cipta

Farid. Moh, Daryanto. 2015. “ Bimbingan Konseling Paduan Guru BK dan Guru Umum", Yogyakarta: PT. Gava Media

Febru Aies Erna.2011,"Asesmen dan Evaluasi", Yogyakarta: Aditya Media Publishing

Hallen. 2002. "Bimbingan dan Konseling”, Jakarta: Ciputit Press

Hidayah Rifa. 2009. "Psikologi Pengasuhan Anak", Malang: Suksess Offset

Latif Muchtar. 2013. "Orientasi Baru Pendidikan Anak Usia Dini”, Jakarta : Kencana

Mahmud. 2011. " Metode Penelitian Pendidikan”, Bandung: Pustaka Setia

Moleong, J.Lexy. 2005. “Metode Penelitian Kualitatif”, bandung: PT. Remaja Rosda Karya

Munir Amir, Samsul. 2010. "Bimbingan dan Konseling Islam” Jakarta: Amzal

Mursyid. 2016. " Pengembangan Pembelajaran PAUD”, Bandung: PT. Remaja Rosdakarya

Nugraha, Ali. 2011. "Metode Pengembangan Sosial Emosional”, Jakarta : Universitas Terbuka

Purnomo Sigit. 2011, "Bimbingan dan Konseling dalam Ontology", Yogyakarta: Gala Ilmu Semesta

Rindi Lelly Anggaraeni. 2014. " Proses Pembelajaran inklusi untuk Anak Berkebutuhan Khusus Kelas V SD Negeri Giwangan Yogyakarta", Yogyakarta: UIN Sunan Kalijaga

Sugiono. 2011. "Metode Penelitian Kuantitatif Kualitatif $R \quad \mathcal{E} \quad D$, Bandung: Penerbit Alfabeta

Suryadi. 2009. “Buku Pegangan Bimbingan dan Konseling untuk PAUD ( 
Pendidikan Anak Usia Dimi), Yogyakarta : Diva Press

Sutirna. 2013. " Perkembangan dan Pertumbuhan Peserta Didik", Yogyakarta: CV. Andi Offset

Takdir Ilahi, Mohammad. 2013. "Pendidikan Inklusif”, Yogjakarta: Ar Ruzz Media.

Tohirin. 2009. "Bimbingan dan konseling di Sekolah dan Madrasah", Jakarta: PT Raja Grafindo Persada.

UU RI Nomor 20 tahun 2003 tentang SIKDISNAS.

Wardati. 2011. "Implementasi Bimbingan dan Konseling di Sekolah”, Jakarta: Prestass Pustakarya

www.Universitassanatadharma.html

Yuliani. 2013. " Konsep Dasar Pendidikan Anak Usia Dini”, Jakarta: PT. Macanan Jayana Cemerlang 